and saddened the entire commonwealth and the nation as well. Few public men of the Hawkeye state had attained in early life such a high degree of popularity and acclaim, or had greater promise of future power and influence.

When among his intimates Senator Dolliver enjoyed personal visits and social gatherings. He was a rare and entertaining storyteller, and appreciated a joke either about himself or another. The late Sen. Geo. M. Titus, of Muscatine, wrote some years ago a short sketch of Dolliver in this role, which is also worthy of reproduction in print. It reveals the fine sense of humor and jovial spirit of camaraderie relished by this greatly admired Iowan in companionship with those he loved to meet, and with whom he so often associated.

Also the late Sen. Addison Parker, of Des Moines, wrote in an interesting way of the great battle waged by the Republican "insurgents" in the United States senate in 1909, in which Senator Dolliver joined. This group comprised those from midwestern states. They challenged the leadership of Senator Aldrich upon the tariff bill, in seeking to write into legislation the party platform pledge and fulfill President Taft's campaign speeches for a revision of the tariff schedules downward. This was a culminating epoch in Dolliver's notable career and worthy of presentation in a symposium of views upon his course in public life. Extracts from a manuscript of Senator Parker illuminate Dolliver's part in this amazing revolt of midwestern statesmen.

\title{
POSSESSED RARE ORATORICAL ABILITY
}

By William R. BoYD

Those of you who have listened in on this program learned how Leslie M. Shaw was started upon his distinguished career in public life because of a speech made at Denison, Iowa, during the middle nineties, on the 
money question. The subject of this afternoon's sketch made his debut in politics by a speech of another kinda strictly political speech, designed to appeal not so much to the reason of his auditors perhaps, as to their emotions.

The event was in 1884. Mr. Dolliver had come to Iowa from Virginia, where he was born in 1858, the son of a Methodist circuit rider. He was brought up in a home in which piety and poverty were mingled, in varying proportions. There was more piety than poverty perhaps, but there was plenty of the latter.

I would like to digress at this point, long enough to pass along to you a story of "Father" Dolliver, as he was affectionately known after his son had attained fame, and he lived with him in Washington. He had lost a leg and walked with crutches. He was a rugged character, who dressed conservatively. One day he was coming out of the congressional library-at that time one of the most beautiful buildings in Washington-especially its interior. A young smart alec met him as he was coming out, and, thinking to have some fun with the old man, said: "Hello, Uncle, have you been in to see the congressional library?" "Yes, son", said Father Dolliver. "What do you think of it?" asked the S. A. "Well, I'll tell you what I think of it," said the retired circuit rider. "I never expect to see anything quite as beautiful as this until I see it in the House not made with hands."

A newspaper man overheard the colloquy, and put Father Dolliver's description of that beautiful building on the wire. It went 'round the world. From that type of a sire and from a sainted mother, the great orator and statesman, whose name was a household word in Iowa for more than a quarter of a century, sprang.

But, to go back to our narrative. The year 1884 found the party to which Mr. Dolliver belonged in not very favorable circumstances. In his own state, the championship of prohibition was working havoc with the 
party. Nationally, it was divided between those who idolized James G. Blaine, and those who didn't trust him.

Mr. Dolliver had come from his native state to Iowa in 1878, and located at Fort Dodge. He had entered upon the practice of law with a brother, but as yet had gained neither fame nor fortune in his chosen profession. He was an eloquent speaker, however-a marvelous conversationalist, and he had attracted the notice and gained the favor of former Gov. C. C. Carpenter, a fellow townsman, who introduced him to the then "king-maker" of Iowa, James S. (Ret) Clarkson, editor of the Des Moines Register. It was at Mr. Clarkson's instance that the politically ambitious young lawyer from Fort Dodge was called upon to make the keynote speech at the Republican state convention, which convened August 20 th of that year.

\section{His First Thrilling Speech}

I was too young to have been in a position to hear that speech-but a man with whom I was afterward associated in the editorship of the Cedar Rapids Republican, Cyrenus Cole, heard it, and he has thus described it in his "History of Iowa":

"The audience matched the orator. It was made up of men who represented the leadership of Republican politics in the state, and on the stage, as the honored guest, sat Gen. William T. Sherman. It was the hour and the honor of which the young man had dreamed, and which most of all things he had coveted. Those who had come to wonder, and the few who had come to admire, were instantly alike thrilled. They were made to realize that never before had they heard anything like it in Iowa. The very manner of the orator pleased them and his voice thrilled them. The gestures were many, not only of the arms and hands, but of the head and the entire body, but they fitted the words. The whole man was in action. The harmony was physical, oral and mental. The sentences were stately and the rhetoric gor- 
geous. There were flashes of wit and ever the genial glow of humor. There was praise and sarcasm, eulogy and opprobrium, and all so rapidly and ineffably mingled and intermingled that those who listened sat spellbound and bewildered. The auditors at times punctuated every sentence with their applause. They laughed often and sometimes they were almost moved to tears."

Dolliver possessed all the equipment of a great orator: a commanding presence, a full rich voice, imaginationone from whose lips it was natural for words to "bud and blossom."

In later years, I heard Mr. Dolliver speak on the floor of the house, and on the floor of the senate, and "on the hustings." Mr. Cole's description of him in action in his initial great speech is, I think, a perfect picture of him when he was roused and in the midst of political battle. He spoke after this fashion in one of the most memorable campaigns he ever made-not for himself, but for his friend and colleague, Senator Allison, whom he loved and honored as a son might love and honor a father.

After that convention address, invitations to speak came to him, not only throughout Iowa, but in various parts of the nation. He was ambitious to go to congress, and was a candidate for that office in 1886 , but was defeated on the 188th ballot. It was the custom in those convention days, when the contest had been settled, to call on both the successful and the unsuccessful candidates for speeches. When Dolliver took the platform, he likened himself to the fellow in Dante's "Inferno," who appears with his own head on the platter. Years later I happened to be in a company, of which Senator Dolliver was one, when somebody asked him: "Dolliver, was that speech you made, likening yourself to the fellow in Dante's 'Inferno,' who appears with his own head on a platter, that time you were defeated in 1886, impromptu or not?"

"I'll tell you about that," he said. "Between the time the county conventions were held and the time for the 
congressional convention to assemble, I tried to see as many delegates to the latter convention as possible. One day, just about noon, I drove into a farmyard to call on the owner, who was a delegate. He invited me to stay to dinner, but wouldn't even let me go to the barn to help put up my horse. I was ushered into the parlor which, after the manner of that day, had in it a marble-topped table on which had been placed a huge copy of the Scriptures and a copy of Dante's 'Inferno' illustrated by Dore. Having been brought up on the Bible, but not being very well acquainted with Dante, I took up the latter volume, and came across a picture of that fellow with his own head on the platter. It flashed through my mind: Why he's in the same position that a man is who has to make a speech before a convention that defeats him. So I wrote out and committed two speeches-one to be used if I won, and the other to be used if I lost. I am like Mark Twain. My best extemporaneous speeches are made after I have had at least two weeks in which to prepare."

Two years later Dolliver was again a candidate for the congressional nomination. This time he won on the 110 th ballot, and started upon a career in national politics which was to grow in influence and power until the day of his death. At this point, I should say that Dolliver's speeches in congress were altogether different from those which have been described. There he appealed not so much to the emotions as to reason. $\mathrm{Mr}$. Cousins records that he was one of the very few men who commanded absolute quietude when he spoke in the house.

\section{Received Advice From Allison}

I was walking home with him one evening from a party in Washington, to the hotel where he lived and where I was stopping temporarily. I said something about the great career he was having, and he said: "I think you exaggerate, but if I am becoming a useful public servant, I am greatly indebted to the old Senator (Allison)." 
He then went on to tell me about it. "You know I came into public favor and to public office as an orator. I had invitations to speak here, there and everywhere, and I accepted as many as I could. One night he and I were sitting on the veranda of Senator Allison's house on Rhode Island avenue in Washington, I having had dinner with him. We sat there smoking in silence for quite a while. Finally the senator said to me: "Jonathan, I am beginning to get worried about you." "Worried!" I exclaimed. "Yes, worried. You are constantly being referred to as the 'brilliant Mr. Dolliver.' You are brilliant, Jonathan, but I have been here for a long time, and I've seen a lot of brilliant fellows come-and go. Now, Jonathan, if you want to have a long and useful career in public life, I think I can tell you how to go about it."

I expressed my willingness to be taught, and he continued: "Select some thing in government in which you are particularly interested, and master it. Learn more about it than anyone else. Have it at your fingertips. If you will do this, with your gifts, you can stay in public life as long as you want to. No one will ever be able to supplant you."

And then he gave me another bit of advice. It was this: "Don't speak as frequently as you have been doing. Nobody can strike twelve every time. Don't accept any invitation to speak unless you have time to prepare yourself thoroughly. Then you will always' be at your best, and you will never disappoint your audience, or lose prestige. Moreover, you will have more time for study. One cannot grow without that." "I took that to heart," said Dolliver. "I concentrated on the tariff. It was a difficult and an intricate subject. I made up my mind, however, if possible, to master it. I haven't arrived yet, but I hope to." As will later appear, it was in this field that he was to break away from the majority of his party, toward the end of his life. 


\section{TrIBUte to ROBERT EMMET}

In seeking to give a word picture of one so distinguished for his oratory as Senator Dolliver, one would certainly be remiss if he did not give some illustration of this gift. A pen picture of him in the heat of political controversy and exhortation has been given. Excerpts from such addresses, as a rule, do not read as well as they sound. I have, therefore, chosen excerpts from two addresses made on special occasions, both non-political. The first is from an address on Robert Emmet, the Irish patriot and martyr, delivered at historic Cooper Union Hall, New York City, while Mr. Dolliver was still a young man, March 3, 1892.

"The anniversary suggests no arch of triumph. It gives to the imagination no pageant of victory. It recalls a child learning the first lessons of patriotism at the fireside of an illustrious family; a youth expelled from school because he would not become an informer; a wanderer in strange capitals, taking counsel in blind credulity with Bonaparte and Tallyrand, the one a professional butcher, the other a professional liar, an enthusiast, dreaming of war with no armies, and of military exploits without money; a fanatic, throwing himself upon the strongholds of an established government at the head of an insignificant mob; a fugitive, forsaking the way of safety and returning to the hands of the police, for a last word with the girl he loved; a prisoner, despising the aid of lawyers and refusing to call witnesses in his own behalf; a convict, making the dock in which he stood famous and endeared by the passion of an inspired eloquence; a piece of bleeding earth cast into potter's field, for obloquy and oblivion, without the ceremony of a prayer or the poor service of a tear."

\section{Tribute to Humble Parents}

The second is from a fraternal address before a conference of the Methodist Episcopal Church, South in one of the efforts on the part of both branches of the 
church, disunited because of the war between the states, to find a common meeting ground when they could again clasp hands in lasting unity and become again one body. This consummation, long devoutly hoped and prayed for, has now been realized. This conference was held in 1898 . Mr. Dolliver followed a distinguished Methodist divine, Dr. Berry. Referring to Dr. Berry's address, Mr. Dolliver said:

"My colleague has spoken with reverence and admiration of the immortal names of Methodism, of the mighty men whose fame fills all the churches and as he recited the roll of these great names I saw how this vast assembly was thrilled by the heroic legends of the past. But somehow while he was speaking there kept coming before my eyes the picture of a quaint old parsonage, with a weather-beaten little church across the road, just on the other side of your Maryland mountains, and I could see a figure, now bent under the weight of years, riding up to the parsonage gate, erect and stalwart; and could catch the merry laughter of the preacher's girls and boys as he tossed them one after another upon the back of his itinerant horse; I heard again the voice of one whose gentle face, now radiant in the eternal beauty, lost its lines of care as she listened to the simple story of the week's labor on the circuit, of the conversions at the mourner's bench, of the probationers admitted on trial, of the funeral of some old saint, of the marriage of happy lovers, and the modest wedding fee, and all the joys and sorrows of the arduous little world in which we lived."

He was describing his own father and mother, and their humble home. Could anyone have described it more eloquently, or more touchingly?

Following this excerpt, he pointed out that there is always enough to say about the greatest men-about the "choice and gifted few whose power and genius mould and shape the opinions of the time"-and that nobody 
ought to complain of this-but that back of these, in every great movement and organization there are a multitude "too humble for the noise of earthly fame, whose names are never seen in print except in the annual minutes," but whose sacrifices enrich the spiritual life of our world.

\section{CONSIDERED FOR VICE PREsIDENCY}

In 1900, after nearly twelve years of distinguished service in the House of Representatives, where he was both a legislator and an orator, Mr. Dolliver had gained such prestige that he was seriously considered for the vice-presidency, being the choice of the president due for renomination that year, William McKinley. But the glamorous figure of Theodore Roosevelt, who had captured the imagination of the American people by his exploits in the Spanish-American war, was also a candidate, and it soon became apparent that no one could prevail against him.

The year following this, Sen. John H. Gear, long a stalwart in the public life of Iowa and the nation, died. Leslie M. Shaw was governor, and was ambitious himself to go to the senate. He might have resigned and fulfilled his ambitions through appointment by the lieutenant governor, or subsequent election by the legislature. $\mathrm{He}$ put that ambition aside, however. He appointed Dolliver to the senate, where he remained a notable figure until he too died in office.

Came the year 1908. Senator Allison's sixth term was drawing to a close. Iowa had enacted the primary system for the selection of candidates for state and national office. It was the general expectation that Allison would succeed himself. But there had come to the front in Iowa, during the last ten years, an attractive and brilliant man-ambitious from the first to go to the senate, Albert B. Cummins. He challenged Senator Allison's right to continue longer in public life. At the time, and in retrospect, it seemed a vast mistake. Had Mr. 
Cummins waited a very brief space, he would have realized his ambition without the bitterness which that contest engendered.

I happened to be in Washington while the campaign was in progress, and chanced to be introduced to Elihu Root-the very personification of intellectuality. I doubt if he ever acted upon his emotions. When he took my hand, he looked at me searchingly, and said: "Are you going to commit the unpardonable sin out in your state?" "I think I know what you mean, Mr. Secretary," I replied. "I think not." "I want to say this," he continued, "it is not Senator Allison who is on trial-it is the people of Iowa. He should be returned, if he were drawing his last breath, because of what he has done. Here in Washington we cannot understand it at all."

As I said, in my sketch of Senator Allison-he had none of the qualities which fitted him for a rough-andtumble primary contest for public office. Moreover, he was an old man, and unable to make the effort physically. In this crisis, his comparatively young and robust colleague went forth to do battle for him. Probably no such series of speeches was ever made "on the hustings," as was made by Dolliver in that campaign. Mr. Cole characterized this campaign as the most superb effort of Dolliver's life. "Into no other subject," he writes, "did he ever put so much of his heart or so much of himself. He drew upon the whole range of literature, from the wisdom of Solomon to the raptures of David; from the philosophies of Cicero and the wit of Franklin ... He poured praise and eulogy on Senator Allison-on his adversary he heaped sarcasm and invective."

Senator Allison was nominated to succeed himself, but died within two months after the contest ended. Mr. Cummins was governor. He called an extra session of the legislature, at which a special senatorial primary law was enacted, and he was nominated, then was elected to succeed Senator Allison in the senate, and thereafter 
resigned as governor. Senator Dolliver found himself with a colleague who quite naturally would be his mortal enemy politically.

\section{Aligned Himself With Cummins}

Then came a situation and action on the part of Senator Dolliver, which was the cause of much bitterness at the time, and no end of speculation as to why he did what he did. A revision of the tariff was on. As I said before, Dolliver had made the tariff his specialty. In general he had been known as a stalwart, but on this question he parted company with a majority of his party in the senate, and aligned himself, so far as the tariff was concerned, with his colleague, $\mathrm{Mr}$. Cummins. $\mathrm{He}$ opposed, with all the gifts he had, two schedules in the pending measure-the cotton schedule and the wool schedule. Upon the high priests of protection he poured forth his invective with a ferocity which almost equalled that which he had displayed in the Allison-Cummins campaign. Many old friends were estranged. He gained new ones in their stead, but he was not happy. Mr. Cole hints that disappointment in not being appointed chairman of the appropriations committee of the senate, to succeed Mr. Allison, was at least part way responsible for the action he took. I cannot agree with my dear dead friend in this. If Dolliver had been looking out solely for himself, he would never have burned all of his bridges behind him as he did in the Allison-Cummins contest. I think he must be given credit for honesty in his position on the tariff. But the estrangement his action brought about saddened his latter days. It is said that he planned to assemble all his old friends and all of his new friends to attend a great reconciliation party at Fort Dodge, and, as Mr. Cole puts it: "To live the rest of his days in the love of all whom he loved." Alas-this consummation was not realized. It might have been, but for his sudden and untimely death. Sitting one autumn afternoon on the porch of his Fort Dodge home, his heart, once stout 
as any heart that ever beat, failed him and he died at the zenith of his power. Today he is a great memory, and I think a gentle one.

\section{DOLLIVER AS A CAMPAIGNER}

By Sen. Geo. M. Titus

Senator Dolliver was the most efficient and influential campaigner that I ever knew while he was a member of the house and afterwards a member of the senate. In all campaigns our local committees in Muscatine county, my home county, always made a great effort to secure at least one speech from Senator Dolliver during the campaign.

Being deeply interested in politics myself, I made it a point every time that Senator Dolliver visited Muscatine to entertain him at my home inviting several local politicians as guests at the same time for evening dinner. It was our custom on such occasions to gather in the living room and just listen to Senator Dolliver tell us about his experiences in politics and about the public men he had met in Washington.

I remember on one occasion a good deal of what the senator told us. He said Secretary of State Blaine was a great politician, but that he made many promises to his political friends but was not always able to redeem all of those promises. To illustrate Blaine's characteristics Dolliver told us of a friend by the name of Emler who was quite a campaigner, and after he had finished the campaign he, Emler, came to Dolliver, then a member of the house and said, "Now, Dolliver, I am through with the campaign and haven't anything to do. I wonder if you would go with me to see Secretary of State Blaine and see if he would give me a job." "I eagerly went with Emler on the appointment to see Blaine," said Dolliver. "I remember how cordially Blaine received us. He 
Copyright of Annals of Iowa is the property of State of Iowa, by \& through the State Historical Society of Iowa and its content may not be copied or emailed to multiple sites or posted to a listserv without the copyright holder's express written permission. However, users may print, download, or email articles for individual use. 